\title{
Decision aids to support decision making in dementia care: A systematic review
}

Nathan Davies*

Centre for Ageing Population Studies, Research Department of Primary Care and Population Health, University College London, Rowland Hill Street, London, NW3 2PF, UK

Centre for Dementia Palliative Care Research, Marie Curie Palliative Care Research Department, Division of Psychiatry, University College London, Tottenham Court Road, London, W1T 7NF n.m.davies@ucl.ac.uk

Brooke Schiowitz

Centre for Ageing Population Studies, Research Department of Primary Care and Population Health, University College London, Rowland Hill Street, London,

NW3 2PF, UK

brschiow@gmail.com

Greta Rait

Priment Clinical Trials Unit, Research Department of Primary Care and Population Health, University College London, Rowland Hill Street, London, NW3 2PF, UK

g.rait@ucl.ac.uk

Victoria Vickerstaff

Centre for Dementia Palliative Care Research, Marie Curie Palliative Care Research Department, Division of Psychiatry, University College London, Tottenham Court Road, London, W1T 7NF v.vickerstaff@ucl.ac.uk

Elizabeth L Sampson

Centre for Dementia Palliative Care Research, Marie Curie Palliative Care Research Department, Division of Psychiatry, University College London, Tottenham Court Road, London, W1T 7NF

Barnet Enfield and Haringey Mental Health Trust Liaison Team, North Middlesex University Hospital, Sterling Way, London N18 1QX, UK.

e.sampson@ucl.ac.uk

Running title: Decision aids dementia 


\section{ABSTRACT \\ Objectives}

We aimed to critically evaluate decision aids developed for practitioners and caregivers, when providing care for someone with dementia or for use by people with dementia themselves.

Decision aids may be videos, booklets or web based tools which explicitly state the decision, provide information about the decision, and summarise options along with associated benefits and harms. This helps guide the decision maker through clarifying their values they place on the benefits or harms of the options.

\section{Design}

We conducted a systematic review of peer reviewed literature in electronic databases (CINAHL, The Cochrane Library, EMBASE, MEDLINE and PsychINFO) in March 2018. Reference lists were searched for relevant articles and citations tracked. Data was synthesised with meta-analysis and narrative synthesis. Articles were eligible if the decision aid was 1) about dementia care, 2) an evaluation of a decision aid, and 3) intended audience was professionals, caregivers or people with dementia.

\section{Results}

We identified 3618 studies and 10 were included, covering three topics across six decision aids: 1) support with eating/feeding options, 2) place of care and 3) goals of care. The mode of delivery and format of the decision aids varied including paper-based, video and audio-based decision aids. The decision aids were shown to be effective increasing knowledge and the quality of communication. The meta-analysis demonstrated decisions are effective in reducing decisional conflict among caregivers (Standardized Mean Difference (SMD) $=-0.50,95 \%$ CI $(-0.97,-0.02)$ ).

\section{Conclusions}

Decision aids offer a promising approach for providing support for decision making in dementia care. People are often faced with more than one decision, and decisions are often interrelated, the decision aids identified in this review focus on single topics. There is a need for decision aids which cover multiple topics in one aid to reflect this complexity and better support caregivers.

Keywords: Dementia, decision making, decision aid, decision support tool 


\section{INTRODUCTION}

Dementia is a chronic neurodegenerative condition causing cognitive and functional decline (Alzheimer's Disease International, 2015). Throughout the course of a person's dementia, important decisions have to be made. Decision-making begins shortly after diagnosis with decisions about everyday life including financial and household decisions. As the condition develops, decisions may become more challenging, including decisions about treatment end of life care (Lamahewa et al., 2018, Davies et al., 2018, Davies et al., 2016).

Despite international aims to increase advance care planning among people with dementia (Department of Health, 2008), many people reach the end of life without an advance care plan (Saini et al., 2016). Many factors may contribute to a lack of advance care plans, including a reluctance to discuss death and dying, denial about the diagnosis, but also importantly a reluctance from professionals to discuss end of life (Moore et al., 2018).

Caring for a person with dementia is one of the most difficult and stressful forms of caregiving (Molyneaux et al., 2011), with carers experiencing uncertainty (Davies, 2015, Davies et al., 2014, Lamahewa et al., 2018). Decisions are often left for caregivers to make alone or through a process of shared decision making with professionals, on behalf of the person with dementia (Emanuel and Emanuel, 1992). Lack of planning means that decisions need to be made quickly when a crisis occurs, possibly leading to undesired hospital admissions, and poor quality care (Davies et al., 2014). Caregivers, professionals and the individual themselves may benefit from support in making decisions, particularly at transition points including the end of life.

Decision aids guide the decision maker through clarifying their values they place on the benefits or harms of the options. They can take various forms including booklets, pamphlets, videos or web based tools. Decision aids explicitly state the decision, provide information about the decision, and summarise options along with associated benefits and harms. They have been defined as: "interventions designed to help people make specific and deliberated choices among options (including the status quo), by making the decision explicit and by providing (at the minimum) information on the options and outcomes relevant to a person's health status as well as implicit methods to clarify values. The decision aids may include: information on the disease/condition; 
costs associated with options; probabilities of outcomes tailored to personal health risk factors; an explicit values clarification exercise; information on others' opinions; a personalized recommendation on the basis of clinical characteristics and expressed preferences; and guidance or coaching in the steps of making and communicating decisions with others" (Stacey et al., 2017).

There is evidence that patient decision aids are acceptable and effective in the general population (Elwyn et al., 2006), including improving patient knowledge and expectations. Decisions aids developed for use in dementia improve efficiency and quality of some decisions and are helpful for presenting balanced and evidenced based information to caregivers (Hanson et al., 2011). Several reviews focussed on decision making processes within dementia care itself, including the involvement of people with dementia and/or caregivers in the decision making process (Miller et al., 2016, Petriwskyj et al., 2014) and their needs (Barker et al., 2017). No review has evaluated decision making interventions with decision aids in dementia care.

The overall aim of this review was to critically evaluate decision aids developed for use by practitioners and caregivers, when providing care for someone with dementia or for use by people with dementia themselves. Specific review questions are:

1) What are the topics/decisions which decision aids focus on and how are these formatted to help with decision making?

2) What topics focusing on end of life care are presented in decision aids?

3) What is the effectiveness and acceptability of decision aids in dementia care from perspective of users?

\section{METHODS}

\section{Design}

A systematic review of randomized control trials (RCTs), quantitative studies, qualitative studies and pre- experimental designs (pre-post studies), following the guidelines from the Centre for Reviews and Dissemination, and the Preferred Reporting Items for Systematic Reviews and 
Meta-Analysis (PRISMA) Statement (D Moher, 2009). The protocol for this review was registered with PROSPERO (CRD42018093107).

\section{Inclusion and Exclusion Criteria}

Articles were included if they met the following criteria: 1) the focus of the paper was on the evaluation of a decision aid; 2) the decision aid was used in dementia care; 3) the decision aid was aimed at professionals, people with dementia, or caregivers.

We excluded articles if: 1) dementia was not the main focus of the decision aid; 2) decision aid was not used for care decisions; 3 ) the intervention only provided information (e.g. information booklets); 4) the decision aid was for diagnostic purposes; 5) commentary pieces, opinion pieces and conference abstracts.

Non-English papers were rapidly appraised using their English abstracts to ensure we did not exclude any relevant articles.

\section{Search Strategy}

We searched CINAHL, The Cochrane Library, EMBASE, MEDLINE and PsychINFO in March 2018. No restrictions were placed on the year of publication to be included in the review. A combination of Medical Subject Headings (MESH), and keywords were used to develop the search strategy which included relevant abbreviations or synonyms. An initial scope of the literature was conducted to enhance and refine the search which was piloted and refined iteratively before finalised (see figure S1 published as supplementary material online attached to the electronic version of this paper at https://www.cambridge.org/core/journals/internationalpsychogeriatrics). We tracked citations using Google Scholar, hand searched reference lists of included and relevant articles and contacted experts in the field. We searched grey literature (using OpenGrey and Greylit) to ensure we were not excluding any important decisions aids through the exclusion of non-peer reviewed journal articles, however did not find any relevant decision aids. 


\section{Selection Procedure}

Article titles and abstracts were screened by one reviewer (author's initials blinded for review) and excluded if they did not meet the inclusion criteria. A second reviewer (author's initials blinded for review) randomly screened $40 \%$ of the included and excluded title and abstracts. Articles considered relevant or lacking sufficient information in the title or abstract were then read in full by one reviewer (author's initials blinded for review). A second reviewer (author's initials blinded for review) screened all included full texts and a sample (40\%) of the excluded full texts. Disagreement or uncertainty about inclusion was decided by a third reviewer (author's initials blinded for review). Figure 1. shows the Preferred Reporting Items for Systematic Reviews and Meta-Analyses (PRISMA) flowchart,

\section{Quality Appraisal}

We appraised included articles using the Critical Appraisal Skills Programme (CASP) tools for qualitative studies (Critical Appraisal Skills Programme (2017)), RCTs (Critical Appraisal Skills Programme (2017)) and an adapted version of the CASP tool for quantitative designs (2018). Studies were not graded or excluded based on their quality appraisal. The appraisal was used to develop the discussion and give weighting to the included studies.

\section{Data Extraction}

A standardised data extraction tool was developed using Microsoft Excel. Data was extracted on study design, aim of the study, intervention details and duration, outcome measures, key findings and the conclusions of the study, data were extracted for each study by one reviewer (author's initials blinded for review) and checked independently by a second (author's initials blinded for review). Where information was lacking, we attempted to contact the authors.

\section{Synthesis}

We synthesised the data using two methods: 1) meta-analysis and 2) narrative synthesis.

\section{Meta-analysis}

Results were analysed according to type of intervention. When treatment effects were reported as continuous variables we extracted (or sought to generate if appropriate) the mean difference (MD) between study arms. When effects were reported as dichotomous we extracted (or sought 
to generate if appropriate) the relative risk (RR) and confidence intervals (CI). If we were unable to standardise results to a RR or MD between study arms, we report alternative statistical results as presented in the relevant papers. When there was sufficient homogeneity in key characteristics across two or more studies, the data were combined across trials in a meta-analysis. A fixedeffects model was used. Heterogeneity of the data synthesis was assessed using the $\mathrm{I}^{2}$ statistic.

Evaluations used different follow up points so scores were chosen from a post intervention point that was common between studies. Where multiple papers reported the same study with different outcome measures, the original RCT was used for meta-analysis. The meta-analysis was performed in Stata version 14 (StataCorp, 2015).

\section{Narrative synthesis}

A narrative synthesis followed guidance from the ESRC methods programme (Popay et al.). This addressed research questions 1-3, using tabulation and thematic analysis. Two reviewers independently coded each of the articles (author's initials blinded for review) and met to discuss their coding frame, discussing definitions and any disagreements. The refined coding frame was then applied to all articles by one reviewer (author's initial's blinded for review) and checked by the second reviewer (author's initial's blinded for review). Finally, results were presented to a third reviewer (author's initial's blinded for review) for comments and refinement. Where limited details were provided in published papers we searched the decision aid depository hosted on the Ottawa Hospital website (https://decisionaid.ohri.ca/), and contacted authors of the articles.

\section{RESULTS}

\section{Description of included studies}

Ten studies were included (Ersek et al., 2014, Hanson et al., 2011, Hanson et al., 2017, Lord et al., 2017, Mitchell et al., 2001, Snyder et al., 2013, Stirling et al., 2012, Volandes et al., 2009a, Volandes et al., 2009b, Einterz et al., 2014): three phase III RCTs reported across five papers (Ersek et al., 2014, Hanson et al., 2011, Hanson et al., 2017, Volandes et al., 2009b, Volandes et al., 2009a); two trials reported two separate sets of analyses using the same sample (Volandes et al., 2009a, Volandes et al., 2009b, Ersek et al., 2014, Hanson et al., 2011); one feasibility RCT and one pilot RCT, which included qualitative findings in the article from process evaluation 
(Stirling et al., 2012, Lord et al., 2017) and three pre-experimental studies (Mitchell et al., 2001, Snyder et al., 2013, Einterz et al., 2014) (see Table 1).

Six different decision aids were reported and evaluated in the 10 studies. Articles containing the same intervention were included in the systematic review because they measured different outcomes or used different methods of evaluation, which added to the discussion. Five of the decision aids were targeted at caregivers or surrogate decision makers (Ersek et al., 2014, Hanson et al., 2011, Hanson et al., 2017, Lord et al., 2017, Mitchell et al., 2001, Snyder et al., 2013, Stirling et al., 2012), while one decision aid targeted both people with dementia and caregivers/surrogate decision makers (Volandes et al., 2009a, Volandes et al., 2009b). Three main topics were covered; support with eating/feeding options, place of care and goals of care.

Two moved away from a traditional paper-based or work book model and used videos (Volandes et al., 2009a, Volandes et al., 2009b, Hanson et al., 2017) of late stage dementia alongside an audio narrative. In the goals of care video decision aid there was also a subsequent structured care plan meeting (Hanson et al., 2017, Einterz et al., 2014). Mitchel and colleagues developed a 40 minute audiotape which was used to guide decision makers through a booklet and personal worksheet (Mitchell et al., 2001), this was later adapted to develop a new decision aid to consist of a written decision aid with the option of an audio component for those with vision or literacy impairments (Hanson et al., 2011).

All the decision aids aimed to reduce decisional conflict and caregiver burden, but measured different outcomes. Outcomes included decisional conflict, frequency of provider discussions, quality of communication, concordance with clinicians on goals of care, advance care planning problem score, carer burden, preferences for care. The topics of the decision aids were varied with a mix of proactive and reactive planning, more information on the content of the decisions aids is discussed below in the narrative synthesis.

\section{Quality appraisal}

All three of the phase III RCTs included were of good quality using the CASP checklist (Critical Appraisal Skills Programme (2017)) (Ersek et al., 2014, Hanson et al., 2011, Hanson et al., 2017, 
Volandes et al., 2009b). However, one of these RCT (Volandes et al., 2009b) was reported in a second paper using a sub-group analysis from the main RCT sample with a separate aim, with a small sample ( $\mathrm{n}=14$ pairs of people with dementia and their surrogates) (Volandes et al., 2009a). Participants were blinded in some trials (Hanson et al., 2017, Hanson et al., 2011, Ersek et al., 2014), however across studies it was not possible to blind researchers. Some included studies had embedded qualitative components as part of the development, feasibility or process evaluations of trials (Stirling et al., 2012, Lord et al., 2017, Snyder et al., 2013), which enhanced the understanding and context of the data for some (Lord et al., 2017), however this data was limited.

Of the included studies which described the development of the decision aid, four decision aids used the Ottawa decision support framework and/or discussed the International patient decision aid standards in their development, strengthening the development and theoretical underpinning of the decision aids (Lord et al., 2017, Mitchell et al., 2001, Stirling et al., 2012, Einterz et al., 2014, Hanson et al., 2011)

\section{Narrative synthesis}

We identified three topics of care addressed by the decision aids; support with eating/feeding options, place of care and goals of care. There were many similarities in how they were delivered and presented to caregivers.

\section{Support with eating/feeding options}

Two of the six decisions aids provided support with making reactive decisions regarding feeding options at the end of life. The first decision aid was developed by Mitchell and colleagues in a pre-post-test study (Mitchell et al., 2001), but was later adapted and reported in three subsequent articles (Ersek et al., 2014, Hanson et al., 2011, Snyder et al., 2013) from the same phase III RCT (Hanson et al., 2011). The aids specifically focussed on the use of a percutaneous endoscopic gastrostomy (PEG) tube, in a hospital or nursing home setting. The two decision aids allowed the user to ask questions of their situation and what their family member would want, presented either as an audiobook with some written components format (Mitchell et al., 2001), or a written booklet (Hanson et al., 2011). 
Mitchell and colleagues' decision aid was evaluated using a before-and after study with substitute decisions makers of cognitively impaired inpatients on acute hospital wards ( $\mathrm{n}=15)$. They demonstrated both increased knowledge and decreased decisional conflict among caregivers (Mitchell et al., 2001), with the greatest impact was on those who were unsure at baseline (Mitchell et al., 2001). A high quality RCT of the adapted decision aid with nursing home residents $(n=256)$ demonstrated the intervention group receiving the decision aid showed statistically significant lower decisional conflict scores after 3 months compared to the control group who received 'usual care', (1.65 vs 1.97, mean difference $-0.32, P<.001$ ), measured using the Decisional Conflict Scale consisting of 16 items scored on a 5-point Likert scale, with a score range of 1-5, with higher scores indicating more conflict (Hanson et al., 2011). Analysis of staffing levels in nursing homes and the effect of the adapted decision aid, on frequency of reported discussions between surrogates and providers demonstrated both the level of staffing and the decision aid enhance surrogate decision making (Ersek et al., 2014). The decision aid was most effective increasing the frequency of provider-surrogate discussions in the intervention compared to control group in the nursing homes with lower levels of staff; either part time physician assistant/nurse practitioner staff ( $26 \%$ vs $51 \%, P<.001)$ or no physician assistant/nurse practitioner staff ( $13 \%$ vs $41 \%, P \leq .001$ ). However, only the decision aid and not staffing levels was associated with a significant reduction in decisional conflict. The decision aids were deemed "highly acceptable" and "useful" by those engaging with the decision aids, measured using a questionnaire (Mitchell et al., 2001).

\section{Summary}

- Decision aids aimed at eating/feeding decisions reduce decisional conflict and increase conversations regarding eating/feeding treatment between caregivers and those in charge of care planning.

- Decision aids were more effective in increasing discussions in nursing homes with lower staffing levels.

\section{Place of Care}

Two decision aids focused on 'place of care decisions' (Stirling et al., 2012, Lord et al., 2017).

One focussed on decisions of long term placement in a care home (DECIDE) (Lord et al., 2017), 
and the other addressed temporary respite care (Stirling et al., 2012). They were designed to enable future care planning, intended for use by caregivers, including family members and significant others. Both adopting an interactive workbook format the decision aids encouraged caregivers to reflect on current living arrangements, including their own health, and the wishes of the person with dementia (Stirling et al., 2012, Lord et al., 2017).

The DECIDE decision aid was the only decision aid which delivered with a decision coach (Lord et al., 2017). The role of the coach was to provide nondirective guidance and support throughout the process of completing the decision aid.

Both decision aids reduced decisional conflict when making place of care decisions (Stirling et al., 2012, Lord et al., 2017), however this was not significant for Stirling and colleagues in a pilot RCT. Stirling and colleagues also reported that the decision aid group had less increase in burden and increased knowledge of the dementia trajectory compared to the control group again however this did not reach statistical significance. The DECIDE feasibility trial with 40 caregivers the intervention group significantly lowered decisional conflict scores on the Decisional Conflict Scale (measured with a range of 0-100 in this study, with lower scores indicating less decisional conflict) compared to the control group after a 10 week follow up (24.72 vs 36.67, mean difference $-11.96,95 \%$ CI -20.10 to 3.83, P=.005) (Lord et al., 2017).

Caregivers evaluated the decision aids as relevant and useful (Lord et al., 2017, Stirling et al., 2012) but some health and care professionals criticised the use of vignettes of other caregivers' experiences; however, vignettes were welcomed by caregivers (Stirling et al., 2012). Caregivers noted that decision aids helped make their own decision clearer, but did not relieve disagreements with other family members (Lord et al., 2017).

\section{Summary}

- The decision aids were both interactive, using a workbook format and encouraged caregivers to reflect on their situation. 
- The studies suggest the use of a decision aid can reduce decisional conflict for users regarding place of care, clarifying decisions, however decision aids did not remove all barriers associated with decision making.

\section{Goals of Care}

Two decision aids aimed to assist people with dementia and their caregivers make decisions about goals of care (Volandes et al., 2009b, Hanson et al., 2017). They had similar approaches, which included showing a video of a person with advanced dementia. The first decision aid from Hanson and colleagues also consisted a structured goals of care meeting (Hanson et al., 2017).

Hanson and colleagues focused on the relationship between caregivers and healthcare professionals aiming to improve the quality of communication (Hanson et al., 2017). Those who received the decision aid scored statistically significant higher than the control group for quality of communication ( 6.0 vs 5.6, mean difference $0.4, P=0.05$ ), and end of life communication (3.7 vs 3.0, mean difference $0.7, P=0.02$ ). Communication was measured using the Quality of Communication questionnaire, a 13 item measure with scores ranging from 0 (poor) to 10 (absolutely perfect). The scale provides an overall score and 2 subscales for general communication skills (6 items), and communication about end of life ( 7 items). They also found greater concordance between family caregiver and clinicians on the primary goal of care at 9 months in the intervention arm compared to control ( $88.4 \%$ vs $71.2 \%, P=0.001)$. During development stages a small $(n=18)$ evaluation of the decision aid showed that caregivers generally (83\%) thought the inclusion of meeting was useful, however some (17\%) reported it simply repeated what they already knew (Einterz et al., 2014). Some felt they already understood everything presented in the decision aid, despite this other caregivers reported it improved clarity, confidence and certainty (Einterz et al., 2014).

The decision aid from Volandes and colleagues focussed on supporting future planning with those who currently did not have dementia, about what they would like to happen if they were to develop advanced dementia (Volandes et al., 2009b). Comparing preferred goals of care among older people when receiving a verbal narrative alone compared to a video decision support tool, they found a greater proportion chose comfort care after receiving a video tool compared to a 
verbal narrative (Volandes et al., 2009b). A smaller sub-analysis of dyads $(n=14)$, found older people and surrogates viewing a video were more likely to have agreement about the older person's end of life preferences compared to those simply listening to a narrative (video:narrative $=4: 1$ ) (Volandes et al., 2009a).

\section{Summary}

- A video decision aid together with a structured meeting improved communication between caregivers and professionals and improved concordance on goals of care after nine months.

- A greater proportion of participants chose comfort care as a goal after using a video decision aid compared to a narrative alone.

\section{Meta-analysis}

RCTs included in the systematic review had sample sizes ranging from 14-255 (total number of participants randomized $\mathrm{N}=1,027$ ) with 2 being pilot and feasibility RCTs. Of the five RCTs (including feasibility/pilot trials), only two provided sufficient data for meta-analysis to examine effectiveness of the decision aids (participants contributing to meta-analysis N=72) (Lord et al., 2017, Stirling et al., 2012). Both RCTs contained a control and intervention arm, each evaluated a single intervention and measured the same outcome. One evaluated the DECIDE intervention which focused on decisional support for long term care placement (Lord et al., 2017) and the second focused on decisional support for respite care decisions (Stirling et al., 2012). The RCTs included in meta-analysis both measured decisional conflict using the Decision Conflict Scale at 3 months post intervention. There was a moderate degree of heterogeneity, $\mathrm{I}^{2}=73.2 \%, \mathrm{p}=0.053$ (See Figure 2. for Forest Plot) but meta-analysis found decision aids are effective in decreasing decisional conflict in caregivers (Standardized Mean Difference (SMD) $=-0.50,95 \%$ CI (-0.97, 0.02)), suggesting increased confidence in decision making and understanding of the decisions.

\section{DISCUSSION}

\section{Overview of results}

The review highlights the topics covered by decision aids used for dementia care; support with eating/feeding options, place of care and goals of care. The narrative synthesis demonstrated 
decision aids for dementia improved a variety of outcomes including decisional conflict was Lord et al., 2017, Stirling et al., 2012, Hanson et al., 2011, Snyder et al., 2013, Ersek et al., 2014); quality of communication (Hanson et al., 2017); concordance rate of preferences of care (Volandes et al., 2009a); and goals of care (Volandes et al., 2009b). When considering the findings of the two included studies combined (Lord et al., 2017, Stirling et al., 2012), the metaanalysis demonstrated there was still a significant effect detected for decisional conflict. Decision aids significantly decreased decisional conflict in caregivers, demonstrating a medium effect size.

Knowledge was measured as a secondary outcome in four of the studies included in the review, with all four studies showing significant increases in knowledge scores after the intervention (Hanson et al., 2011, Snyder et al., 2013, Stirling et al., 2012, Volandes et al., 2009b). However, as some of the data is pre-experimental, feasibility and pilot trials, conclusions about effectiveness are cautious especially as there is a heterogeneity in the topics, delivery and intended audience of the decision aids.

\section{Audience/target}

The decision aids identified are mainly aimed at caregivers or surrogate decision makers. In some cases the surrogate decision maker may be a practitioner. Decision aids may me more beneficial for patients and caregivers, due to their length and how they reflect on wishes and values. Shorter, more applied and pragmatic tools such as heuristics or rules of thumb may be needed for professionals (Davies et al., 2018, Davies et al., 2016, Mathew et al., 2016).

\section{End of life decisions}

All included decision aids were relevant to decisions related to end of life care. Guidance and good practice recommends caregivers should be involved in decisions (van der Steen et al., 2014), and informed decision making is part of a good death (Murray et al., 2004). However, caregivers report limited support regarding end of life decision making and this review only found a small number of decision aids. Our review suggests decision aids may be a useful option to support caregivers, however, they will not remove all barriers such as family conflict which can be common (Lord et al., 2017). The development of decision aids regarding end of life may be particularly challenging as guidance for developing decision aids states that options should be 
provided along with possible outcomes (Elwyn et al., 2006), however the uncertain nature of the dementia trajectory makes this challenging (Stirling et al., 2012, Davies and Iliffe, 2016).

\section{Format and acceptability}

A recent systematic review of support for family caregivers of people with dementia demonstrated that decisional support as part of multi-component online interventions was not well used or appreciated by caregivers (Hopwood et al., 2018). Four decision aids included in this review followed guidance from the International Patient Decision Aid Standards (IPDAS) on format and delivery, providing a much more structured and clear approach, absent in studies in the previous review (Elwyn et al., 2006). However, little detail was provided within the papers on the use of these standards to assess the decision aid quality against the checklist. The decision aids were mainly interactive, encouraging users to explore their views and those of the person with dementia. For many, this was done either through conversations or written reflections, and answering questions and scales to clarify their views. There was limited qualitative data to explore format and delivery of the decision aids from the end users, for example views of specific components.

Many of the decision aids are for completion by the individual decision maker without support, but a meeting to talk to a professional or coach about decisions was seen as beneficial (Stirling et al., 2012, Hanson et al., 2017). This may be particularly key for significant decisions such as at end of life. However, only two decision aids used this approach (Lord et al., 2017) (Hanson et al., 2017). Evidence that the inclusion of a coach with a decision aid may help users, is limited (Stacey et al., 2013, Bunn et al., 2018) but digital health interventions show facilitation can improve uptake and reach (Murray et al., 2018).

\section{Strengths and Limitations}

A strength of this review is the methodological rigour. We conducted a thorough search, contacting authors for further details. The search was strengthened by searching PROSPERO and contacting experts in the field for new or missing studies. The screening of articles and synthesis was conducted by two reviewers. Including both quantitative and qualitative research has allowed for a broader inclusion of studies of decision aids and strengthened the discussion of the topics, content, and acceptability of the decision aids. 
Although there were five RCTs included in the review, one was a feasibility study and one a pilot trial, so it is difficult to make definitive conclusions about effectiveness and acceptability. Due to a range of the interventions and variety of outcome measures used only two studies were valid for meta-analysis and results must be interpreted with caution. Many studies did not provide information on usefulness, usability and acceptability of the decision aids. It was not possible to understand what aspects of the decision aids users found most useful and acceptable which limits the lessons for developing future decision aids in this area. There was limited information across the studies of the consideration of cultural factors and how this influenced acceptability.

\section{Implications for Future Research, Policy and Clinical Practice}

This review has demonstrated the need for research and development of decision aids in dementia and may be particularly helpful at end of life, a period which can involve complex and significant decisions. Decision aid format may need to be adapted depending on target group and age. Secondly, there is need for high quality RCTs powered to test the effectiveness of decision aids for dementia care.

The findings of this review suggest there may be several positive outcomes for caregivers, surrogate decision makers and services when using a decision aid. This review demonstrates decision aids reduce decisional conflict for caregivers when making decisions, suggesting an increase in certainty of options, feeling informed, clarity about decisions, support and confidence. However, it is important that decision aids, especially those regarding sensitive and emotive decisions, are not used without professional support; communication and discussion may be a key part of the process. Finally, in order to see a potential benefit we require carefully planned studies to understand the challenges of using and implementing decision aids in practice.

\section{Conclusions}

Decision aids appear to be well received by caregivers, people with dementia and professionals and show promise in providing support when making significant decisions in dementia care. There is evidence that decision aids reduce decisional conflict, suggesting an increase in confidence and understanding of the decisions that the user of the decision aid is making. 
However, further testing is needed to understand optimal format, content and implementation of the decision aids in dementia and with various end users.

\section{Conflict of interest}

None

\section{Description of author's roles}

ND - Designed the study, secured funding, supervised the search and data extraction, synthesised findings, led writing of the paper.

BS - Conducted the search and data extraction, synthesised findings, contributed to writing the paper.

VV - Supervised the meta-analysis, contributed to writing paper.

GR - Contributed to synthesis, interpretation of findings and writing paper.

ELS - Contributed to data extraction, synthesis, interpretation of findings and writing paper.

\section{References}

BARKER, S., LYNCH, M. \& HOPKINSON, J. 2017. Decision making for people living with dementia by their carers at the end of life: a rapid scoping review. International journal of palliative nursing, 23, 446-456.

BUNN, F. et al. 2018. Supporting shared decision making for older people with multiple health and social care needs: a realist synthesis. BMC geriatrics, 18, 165.

CRITICAL APPRAISAL SKILLS PROGRAMME (2017). CASP Qualitative Checklist [online] [Online]. Available: http://www.webcitation.org/6xDz3wBsA; http://docs.wixstatic.com/ugd/dded87 25658615020e427da194a325e7773d42.pdf [Accessed 01092017 2017].

CRITICAL APPRAISAL SKILLS PROGRAMME (2017). CASP Randomised Controlled Trial Checklist [Online]. Available: http://www.webcitation.org/6xDz89ZeG ; http://docs.wixstatic.com/ugd/dded87 4239299b39f647ca9961f30510f52920.pdf [Accessed 01092016 2016].

D MOHER, A. L., J TETZLAFF, DG ALTMAN AND THE PG 2009. Preferred reporting items for systematic reviews and meta-analyses: The prisma statement. Annals of Internal Medicine.

DAVIES, N. 2015. Talking with family carers about end-of-life care for people with dementia. European Journal of Palliative Care, 22, 6-8.

DAVIES, N. \& ILIFFE, S. 2016. End of life care-why those with dementia have different needs. $B M J, 353$. 
DAVIES, N., MAIO, L., RAIT, G. \& ILIFFE, S. 2014. Quality end-of-life care for dementia: What have family carers told us so far? A narrative synthesis. Palliative Medicine, 28, 919-930.

DAVIES, N., MANTHORPE, J., SAMPSON, E. L., LAMAHEWA, K., WILCOCK, J., MATHEW, R. \& ILIFFE, S. 2018. Guiding practitioners through end of life care for people with dementia: The use of heuristics. PLOS ONE, 13, e0206422.

DAVIES, N. et al. 2016. A co-design process developing heuristics for practitioners providing end of life care for people with dementia. BMC Palliative Care, 15.

DEPARTMENT OF HEALTH 2008. End of Life Care Strategy: Promoting High Quality Care for all Adults at the End of Life. London: Department of Health.

EINTERZ, S. F., GILLIAM, R., CHANG LIN, F., MCBRIDE, J. M. \& HANSON, L. C. 2014. Development and Testing of a Decision Aid on Goals of Care for Advanced Dementia. Journal of the American Medical Directors Association, 15, 251-255.

ELWYN, G. et al. 2006. Developing a quality criteria framework for patient decision aids: online international Delphi consensus process. BMJ, 333, 417.

EMANUEL, E. J. \& EMANUEL, L. L. 1992. Proxy decision making for incompetent patients: an ethical and empirical analysis. Jama, 267, 2067-2071.

ERSEK, M. et al. 2014. Provider staffing effect on a decision aid intervention. Clinical Nursing Research, 23, 36-53.

HANSON, L. C. et al. Improving decision-making for feeding options in advanced dementia: a randomized, controlled trial. Journal of the American Geriatrics Society, 59, 2009-16.

HANSON, L. C. et al. 2017. Effect of the Goals of Care Intervention for Advanced Dementia: A Randomized Clinical Trial. JAMA Internal Medicine, 177, 24-31.

HOPWOOD, J. et al. 2018. Internet-Based Interventions Aimed at Supporting Family Caregivers of People With Dementia: Systematic Review. J Med Internet Res, 20, e216.

ALZHEIMER'S DISEASE INTERNATIONAL. 2015. Dementia Statistics [Online]. Alzheimer's Disease International. [Accessed].

LAMAHEWA, K. et al. 2018. A qualitative study exploring the difficulties influencing decision making at the end of life for people with dementia. Health Expectations, 21, 118-127.

LORD, K., LIVINGSTON, G. \& COOPER, C. 2017. A feasibility randomised controlled trial of the DECIDE intervention: dementia carers making informed decisions. BJPsych Open, 3, 1214.

MATHEW, R., DAVIES, N., MANTHORPE, J. \& ILIFFE, S. 2016. Making decisions at the end of life when caring for a person with dementia: A literature review to explore the potential use of heuristics in difficult decision-making. BMJ Open, 6, doi: 10.1136/bmjopen-2015010416.

MILLER, L. M., WHITLATCH, C. J. \& LYONS, K. S. 2016. Shared decision-making in dementia: a review of patient and family carer involvement. Dementia, 15, 1141-1157.

MITCHELL, S. L., TETROE, J. \& O'CONNOR, A. M. 2001. A decision aid for long-term tube feeding in cognitively impaired older persons. Journal of the American Geriatrics Society, 49, 313-6.

MOLYNEAUX, V., BUTCHARD, S., SIMPSON, J. \& MURRAY, C. 2011. Reconsidering the term 'carer': a critique of the universal adoption of the term 'carer'. Ageing and Society, 31, 422-437. 
MOORE, K. J., GOODISON, H. \& SAMPSON, E. L. 2018. The role of the memory service in helping carers to prepare for end of life: A mixed methods study. International journal of geriatric psychiatry.

MURRAY, E. et al. 2018. A web-based self-management programme for people with type 2 diabetes: the HeLP-Diabetes research programme including RCT. Programme Grants for Applied Research.

MURRAY, M. A., MILLER, T., FISET, V., O'CONNOR, A. \& JACOBSEN, M. J. 2004. Decision support: helping patients and families to find a balance at the end of life. International Journal of Palliative Nursing, 10, 270-277.

PETRIWSKYJ, A., GIBSON, A., PARKER, D., BANKS, S., ANDREWS, S. \& ROBINSON, A. 2014. A qualitative metasynthesis: family involvement in decision making for people with dementia in residential aged care. International journal of evidence-based healthcare, 12, 87-104.

POPAY, J. et al. Guidance on the conduct of narrative synthesis in sytematic reviews.

SAINI, G. et al. 2016. An ethnographic study of strategies to support discussions with family members on end-of-life care for people with advanced dementia in nursing homes. $B M C$ Palliative Care, 15, 55.

SNYDER, E. A., CAPRIO, A. J., WESSELL, K., LIN, F. C. \& HANSON, L. C. 2013. Impact of a Decision Aid on Surrogate Decision-Makers' Perceptions of Feeding Options for Patients With Dementia. Journal of the American Medical Directors Association, 14, 114-118.

STACEY, D. et al. 2013. Coaching and guidance with patient decision aids: a review of theoretical and empirical evidence. BMC Medical Informatics and Decision Making, 13, S11.

STACEY, D. et al. 2017. Decision aids for people facing health treatment or screening decisions. Cochrane Database of Systematic Reviews [Online]. Available: http://cochranelibrarywiley.com/doi/10.1002/14651858.CD001431.pub5/abstract.

STATACORP 2015. Stata Statistical Software: Release 14. College Station, TX: StataCorp LP.

STIRLING, C. et al. 2012. Decision aids for respite service choices by carers of people with dementia: development and pilot RCT. BMC Medical Informatics \& Decision Making, 12, 21.

VAN DER STEEN, J. et al. 2014. White paper defining optimal palliative care in older people with dementia: A Delphi study and recommendations from the European Association for Palliative Care. Palliative Medicine, 28, 197-209.

VOLANDES, A. E., MITCHELL, S. L., GILLICK, M. R., CHANG, Y. \& PAASCHE-ORLOW, M. K. 2009 a. Using video images to improve the accuracy of surrogate decision-making: a randomized controlled trial. Journal of the American Medical Directors Association, 10, 575-80.

VOLANDES, A. E. et al. 2009b. Video decision support tool for advance care planning in dementia: randomised controlled trial. BMJ, 338, b2159. 


\section{Figure 1. PRISMA Flow Chart}

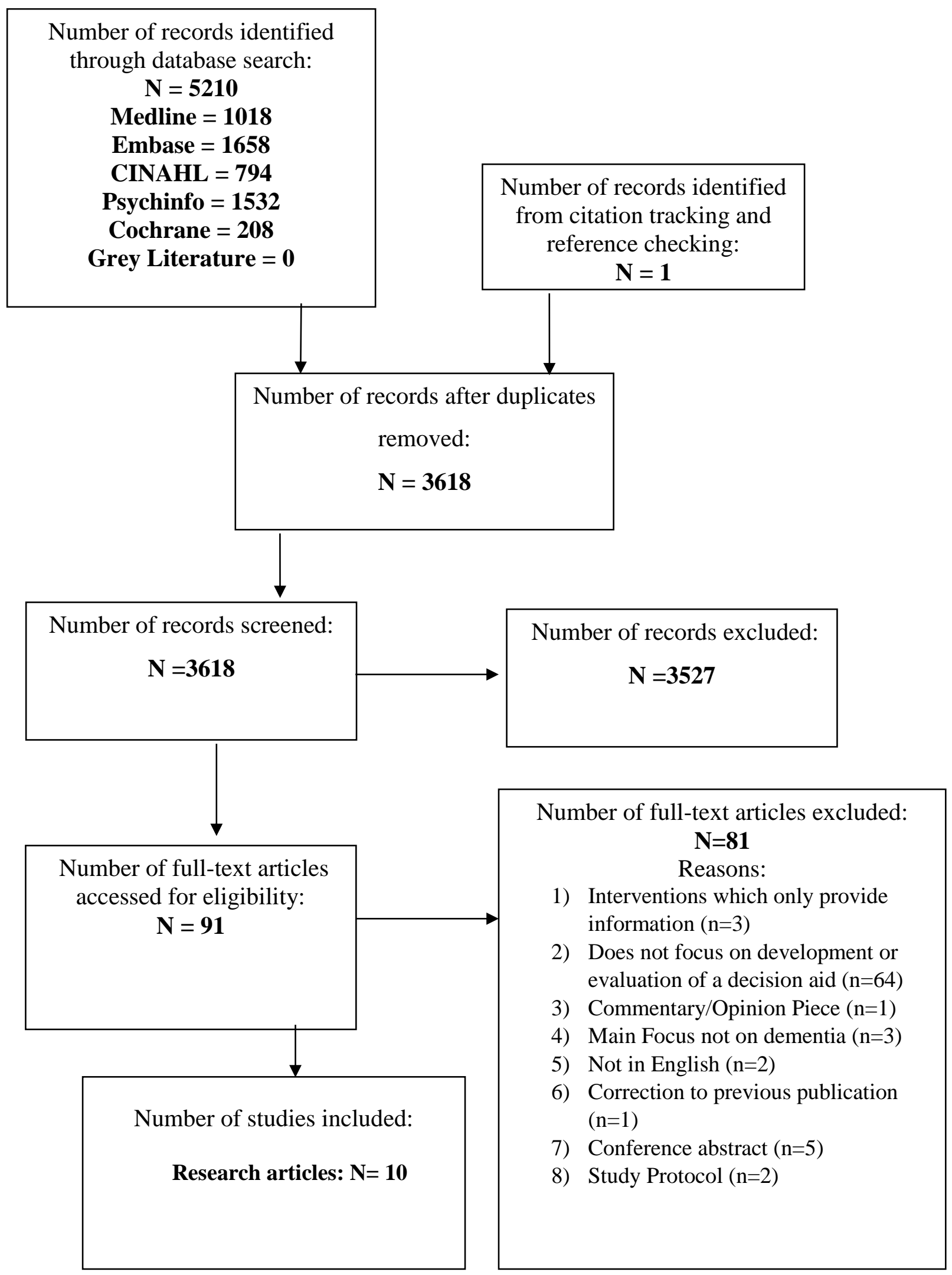


Figure 2. Forest plot

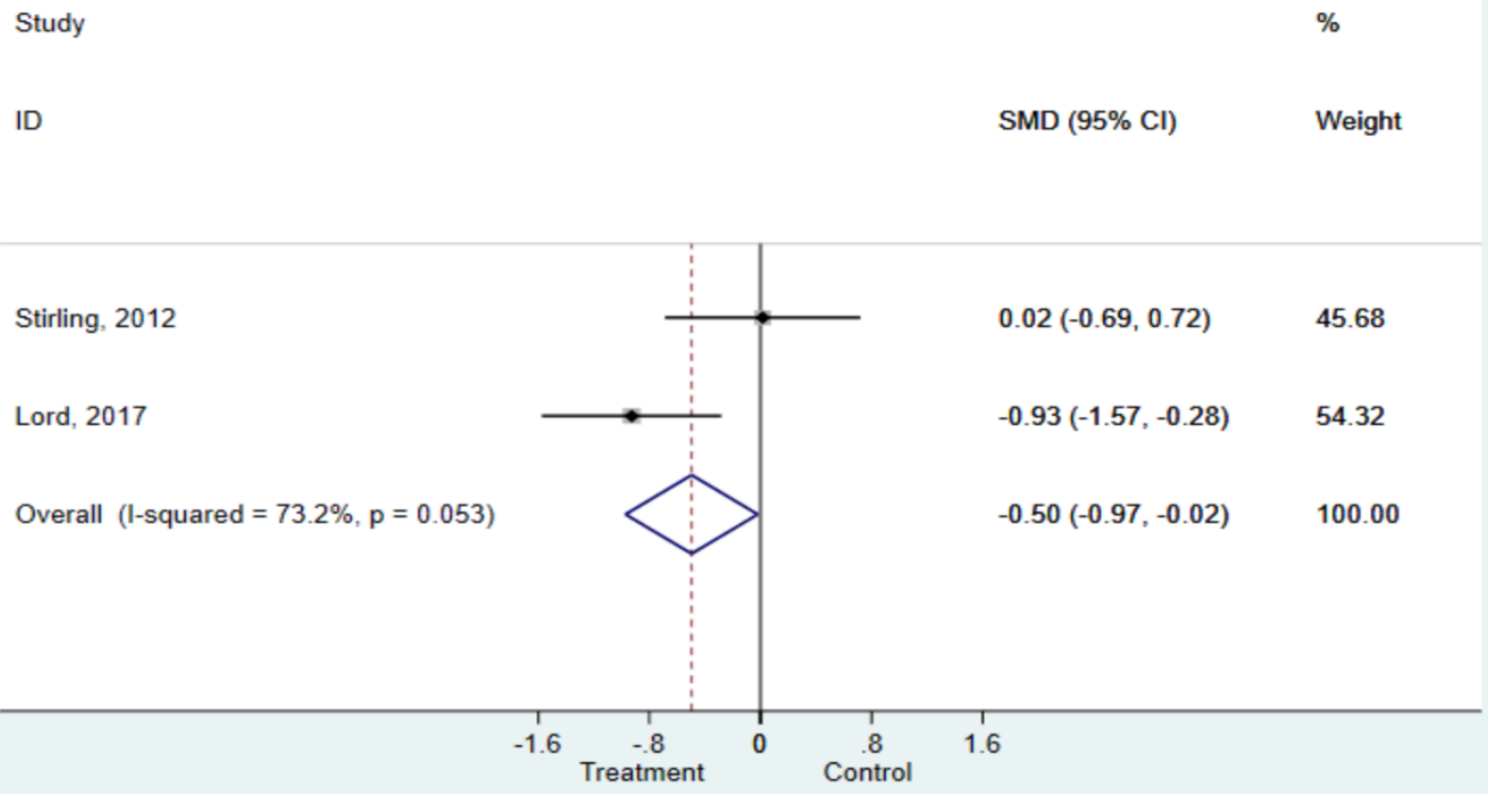


Table 1. Descriptions of the Studies

\begin{tabular}{|c|c|c|c|c|c|c|c|}
\hline Author & Year & $\begin{array}{c}\text { Study } \\
\text { Type }\end{array}$ & $\begin{array}{l}\text { Summary of } \\
\text { Intervention }\end{array}$ & Population & $\begin{array}{l}\text { Primary or main } \\
\text { Outcome Measure }\end{array}$ & Key Findings & Conclusions \\
\hline \multicolumn{8}{|c|}{ Support with eating/feeding options } \\
\hline $\begin{array}{l}\text { Mitchell et } \\
\text { al. } \\
\text { (Mitchell } \\
\text { et al., } \\
2001 \text { ) }\end{array}$ & 2011 & $\begin{array}{l}\text { Before and } \\
\text { After Study }\end{array}$ & $\begin{array}{l}\text { Audio guided booklet } \\
\text { with three modules: 1) } \\
\text { Information on options } \\
\text { and outcomes; 2) Steps } \\
\text { to decision making to } \\
\text { help guide debate based } \\
\text { on the patient's clinical } \\
\text { state, personal values } \\
\text { and preferences; } 3 \text { ) A } \\
\text { worksheet designed to } \\
\text { operationalize these } \\
\text { decision-making steps. }\end{array}$ & $\begin{array}{l}\text { Substitute } \\
\text { decision } \\
\text { makers for } \\
\text { cognitively } \\
\text { impaired } \\
\text { acute care } \\
\text { hospital } \\
\text { inpatients } 65 \\
\text { years and } \\
\text { older (n=15) }\end{array}$ & $\begin{array}{l}\text { Knowledge about } \\
\text { swallowing } \\
\text { problems, } \\
\text { decisional conflict } \\
\text { scale and } \\
\text { predisposition to } \\
\text { feeding tube } \\
\text { placement }\end{array}$ & $\begin{array}{l}\text { Mean score for decision } \\
\text { conflict significantly } \\
\text { decreased after exposure to the } \\
\text { decision aid ( } 2.29 \text { vs } 2.88 \\
\text { p=.004). } \\
\text { Knowledge was significantly } \\
\text { greater after using the decision } \\
\text { aid ( } 84 \% \text { vs } 50.4 \% \text { p=.004). } \\
\text { The biggest impact on } \\
\text { surrogate's predisposition to } \\
\text { tube feeding was among those } \\
\text { who were unsure of their } \\
\text { decision at baseline. } \\
\text { Surrogates who were in favour } \\
\text { or against did not change their } \\
\text { preferences. For those were } \\
\text { unsure two out of seven } \\
\text { remained unsure after the }\end{array}$ & $\begin{array}{l}\text { Decision aid } \\
\text { significantly } \\
\text { increased knowledge } \\
\text { and reduced } \\
\text { decisional conflict. } \\
\text { Particularly useful in } \\
\text { clarifying treatment } \\
\text { preferences for those } \\
\text { who were unsure } \\
\text { about which option } \\
\text { to choose. }\end{array}$ \\
\hline
\end{tabular}




\begin{tabular}{|c|c|c|c|c|c|c|c|}
\hline & & & & & & $\begin{array}{l}\text { decision aid, } 4 \text { decided on } \\
\text { supportive care only, and } 1 \\
\text { chose tube feeding. }\end{array}$ & \\
\hline $\begin{array}{l}\text { Snyder et } \\
\text { al. (Snyder } \\
\text { et al., } \\
2013 \text { ) }\end{array}$ & 2013 & $\begin{array}{l}\text { Pre-Post } \\
\text { study } \\
\text { design }\end{array}$ & $\begin{array}{l}\text { A printed decision aid } \\
\text { which offered } \\
\text { information about } \\
\text { dementia, the potential } \\
\text { feeding options } \\
\text { associated with the } \\
\text { progression of dementia, } \\
\text { advantages and } \\
\text { disadvantages of feeding } \\
\text { tubes versus assisted oral } \\
\text { feeding. }\end{array}$ & $\begin{array}{l}\text { Surrogate } \\
\text { decision } \\
\text { makers of } \\
\text { nursing home } \\
\text { residents with } \\
\text { advanced } \\
\text { dementia and } \\
\text { feeding } \\
\text { problems } \\
(\mathrm{n}=255)\end{array}$ & Decisional Conflict & $\begin{array}{l}\text { After review of the decision } \\
\text { aid, surrogates had } \\
\text { significantly more correct } \\
\text { answers to knowledge of } \\
\text { feeding options after exposure } \\
\text { to the decision aid ( } 15.5 \mathrm{vs} \\
16.8 ; \mathrm{P}<.001 \text { ) and had } \\
\text { decreased expectation of } \\
\text { benefit from tube feeding } \\
\text { ( } 2.73 \text { to } 2.32 \mathrm{P}=.0001 \text { ). } \\
\text { Surrogates had lower } \\
\text { decisional conflict score } 2.24 \\
\text { vs } 1.91 \mathrm{p}<.0001 \text { and were } \\
\text { more certain of their choice } \\
\text { improved from } 1.35 \text { to } 1.05 \\
\text { p=0.0106. }\end{array}$ & $\begin{array}{l}\text { Interaction with a } \\
\text { structured decision } \\
\text { aid significantly } \\
\text { improved caregivers' } \\
\text { knowledge of the } \\
\text { potential feeding } \\
\text { options, lowered } \\
\text { decisional conflict, } \\
\text { and increased levels } \\
\text { of confidence that } \\
\text { assisted oral feeding } \\
\text { is optimal care. }\end{array}$ \\
\hline $\begin{array}{l}\text { Hanson et } \\
\text { al. } \\
\text { (Hanson et } \\
\text { al., 2011) }\end{array}$ & 2011 & $\begin{array}{l}\text { Cluster } \\
\text { RCT }\end{array}$ & $\begin{array}{l}\text { See Snyder et al., } 2013 \\
\text { (Snyder et al., 2013) }\end{array}$ & $\begin{array}{l}\text { Dyads of } \\
\text { nursing home } \\
\text { residents with } \\
\text { advanced } \\
\text { dementia and } \\
\text { their } \\
\text { surrogate }\end{array}$ & Decisional Conflict & $\begin{array}{l}\text { Intervention improved } \\
\text { knowledge scores significantly } \\
\text { (16.8 vs } 15.1 \mathrm{p}<.0001) \text {. After } \\
3 \text { months, intervention } \\
\text { surrogates had lower decision } \\
\text { conflict scores compared to } \\
\text { controls ( } 1.65 \text { vs } 1.97 \text {, mean }\end{array}$ & $\begin{array}{l}\text { The decision aid } \\
\text { improved the quality } \\
\text { of decision making } \\
\text { for surrogates and } \\
\text { their frequency of } \\
\text { communication with } \\
\text { medical providers }\end{array}$ \\
\hline
\end{tabular}




\begin{tabular}{|c|c|c|c|c|c|c|c|}
\hline & & & & $\begin{array}{l}\text { decision } \\
\text { makers } \\
(\mathrm{n}=256 \\
\text { dyads })\end{array}$ & & $\begin{array}{l}\text { difference }-0.32, \mathrm{p}<.0001) \text {, } \\
\text { greater reduction in scores } \\
\text { over } 3 \text { months (-0.60 vs } 0.13 \text {, } \\
\mathrm{p}<.001 \text { ), and were more likely } \\
\text { to discuss feeding options with } \\
\text { a healthcare provider ( } 46 \% \text { vs } \\
33 \% ; \mathrm{P}=.04) \text {. Residents in the } \\
\text { intervention group were more } \\
\text { like to receive dysphagia diet } \\
(89 \% \text { vs } 76 \% ; \mathrm{P}=.04) \text {. }\end{array}$ & $\begin{array}{l}\text { regarding } \\
\text { eating/feeding } \\
\text { preferences. }\end{array}$ \\
\hline $\begin{array}{l}\text { Ersek et } \\
\text { al. (Ersek } \\
\text { et al., } \\
\text { 2014) }\end{array}$ & 2015 & $\begin{array}{l}\text { Cluster } \\
\mathrm{RCT}\end{array}$ & $\begin{array}{l}\text { See Snyder et al., } 2013 \\
\text { (Snyder et al., 2013) }\end{array}$ & $\begin{array}{l}\text { Dyads of } \\
\text { nursing home } \\
\text { residents with } \\
\text { advanced } \\
\text { dementia and } \\
\text { their } \\
\text { surrogate } \\
\text { decision } \\
\text { makers } \\
\text { (n=256 } \\
\text { dyads) }\end{array}$ & Decisional Conflict & $\begin{array}{l}\text { The decision aid was most } \\
\text { effective increasing the } \\
\text { frequency of provider- } \\
\text { surrogate discussions in the } \\
\text { intervention compared to } \\
\text { control group in the nursing } \\
\text { homes with lower levels of } \\
\text { staff; either part time } \\
\text { physician assistant/nurse } \\
\text { practitioner staff ( } 26 \% \text { vs } \\
51 \%, \mathrm{P}<.001 \text { ) or no physician } \\
\text { assistant/nurse practitioner } \\
\text { staff ( } 13 \% \text { vs } 41 \%, \mathrm{P} \leq .001) \text {. } \\
\text { For decisional conflict the } \\
\text { decision aid but not the }\end{array}$ & $\begin{array}{l}\text { The quality of } \\
\text { support for decision } \\
\text { making could be } \\
\text { enhanced with the } \\
\text { decision aid and full } \\
\text { time staffing in } \\
\text { nursing homes, but } \\
\text { the decision aid may } \\
\text { be particularly } \\
\text { helpful in those } \\
\text { homes with lower } \\
\text { staffing levels. }\end{array}$ \\
\hline
\end{tabular}




\begin{tabular}{|c|c|c|c|c|c|c|c|}
\hline & & & & & & $\begin{array}{l}\text { staffing levels was associated } \\
\text { with a significant reduction in } \\
\text { decisional conflict. Decisional } \\
\text { conflict score decreased over a } \\
\text { 3-month period in both the } \\
\text { intervention and control } \\
\text { groups across all staffing } \\
\text { levels, but was only } \\
\text { statistically significant in } \\
\text { nursing homes with part time } \\
\text { or no staffing. }\end{array}$ & \\
\hline \multicolumn{8}{|c|}{ Place of care } \\
\hline $\begin{array}{l}\text { Stirling et } \\
\text { al. } \\
\text { (Stirling et } \\
\text { al., 2012) }\end{array}$ & 2012 & $\begin{array}{l}\text { Mixed } \\
\text { Methods- } \\
\text { Qualitative } \\
\text { and pilot } \\
\text { RCT }\end{array}$ & $\begin{array}{l}\text { Decision aid for living } \\
\text { with dementia (GOLD) } \\
\text { book: paper-based } \\
\text { decision aid, includes } \\
\text { descriptive information } \\
\text { about services that are } \\
\text { available in the } \\
\text { community, descriptive } \\
\text { information about respite } \\
\text { care, vignettes describing } \\
\text { caregivers' experiences, } \\
\text { information about } \\
\text { dementia trajectory, } \\
\text { phone numbers and links }\end{array}$ & $\begin{array}{l}\text { Carers of } \\
\text { people with } \\
\text { dementia } \\
(n=31)\end{array}$ & Decisional conflict & $\begin{array}{l}\text { The intervention has the } \\
\text { potential to attribute to a } \\
\text { reduction in burden and } \\
\text { decisional conflict amongst } \\
\text { caregivers. } \\
\text { The intervention group had } \\
\text { less increase in burden and } \\
\text { greater increase in knowledge } \\
\text { when compared with control } \\
\text { group, however this did not } \\
\text { reach statistical significance. }\end{array}$ & $\begin{array}{l}\text { This study identifies } \\
\text { an important } \\
\text { decisional support } \\
\text { intervention gap for } \\
\text { caregivers in relation } \\
\text { to respite care } \\
\text { decisions. There is } \\
\text { an unmet need for } \\
\text { decisional support } \\
\text { and caregivers } \\
\text { accept the use of } \\
\text { decision aids in these } \\
\text { matters. }\end{array}$ \\
\hline
\end{tabular}




\begin{tabular}{|c|c|c|c|c|c|c|c|}
\hline & & & $\begin{array}{l}\text { for obtaining more } \\
\text { information. Also } \\
\text { includes step by step } \\
\text { scales, which allow users } \\
\text { to weigh their } \\
\text { preferences. }\end{array}$ & & & & \\
\hline $\begin{array}{l}\text { Lord et al. } \\
\text { (Lord et } \\
\text { al., 2017) }\end{array}$ & 2017 & $\begin{array}{l}\text { Feasibility } \\
\text { RCT and } \\
\text { Qualitative } \\
\text { study }\end{array}$ & $\begin{array}{l}\text { DECIDE intervention: a } \\
\text { guided decision aid that } \\
\text { participants read and } \\
\text { completed with support } \\
\text { of a decision coach to } \\
\text { assist in making } \\
\text { decisions regarding care } \\
\text { home placement. }\end{array}$ & $\begin{array}{l}\text { Family carers } \\
\text { of for people } \\
\text { with } \\
\text { moderate or } \\
\text { severe } \\
\text { dementia } \\
(n=41)\end{array}$ & Decisional Conflict & $\begin{array}{l}\text { At the } 10 \text { week follow up, the } \\
\text { intervention group had lower } \\
\text { mean decisional conflict score } \\
\text { which was significant } \\
\text { compared to the control group } \\
\text { ( } 24.72 \text { vs } 36.67 \text {, mean } \\
\text { difference }-11.96,95 \% \text { CI - } \\
20.10 \text { to } 3.83, \mathrm{P}=.005 \text { ). This } \\
\text { remained significant after } \\
\text { controlling for baseline scores. } \\
\text { At follow up there was no } \\
\text { significant difference between } \\
\text { groups in anxiety or } \\
\text { depression scores. In } \\
\text { qualitative interviews, } \\
\text { caregivers noted that the } \\
\text { decision aid did not remove all } \\
\text { decisional barriers. }\end{array}$ & $\begin{array}{l}\text { Initial evidence that } \\
\text { DECIDE manual } \\
\text { may decrease } \\
\text { decisional conflict in } \\
\text { caregivers of people } \\
\text { with dementia. }\end{array}$ \\
\hline
\end{tabular}




\begin{tabular}{|c|c|c|c|c|c|c|c|}
\hline $\begin{array}{l}\text { Hanson et } \\
\text { al. } \\
\text { (Hanson et } \\
\text { al., 2017) }\end{array}$ & 2017 & $\begin{array}{l}\text { Single } \\
\text { Blind } \\
\text { Cluster } \\
\text { RCT }\end{array}$ & $\begin{array}{l}\text { Consisted of two parts 1) } \\
\text { a video decision aid and } \\
\text { 2) a structured meeting } \\
\text { between surrogate } \\
\text { decision maker and } \\
\text { interdisciplinary care } \\
\text { plan team. } \\
\text { The decision aid was } \\
\text { developed based on } \\
\text { Braddock's framework } \\
\text { which included 1) the } \\
\text { surrogates role; 2) } \\
\text { prognosis and goals of } \\
\text { care for medical } \\
\text { treatment of advanced } \\
\text { dementia; 3) treatment } \\
\text { approaches to meet the } \\
\text { primary goals of } \\
\text { longevity, function and } \\
\text { comfort; 4) consideration } \\
\text { of personal goals and } \\
\text { values; 5) the pros and } \\
\text { cons of each choice for a } \\
\text { primary goal and related } \\
\text { treatments. }\end{array}$ & $\begin{array}{l}\text { Nursing } \\
\text { home } \\
\text { residents with } \\
\text { advanced } \\
\text { dementia and } \\
\text { their family } \\
\text { decision } \\
\text { makers } \\
\text { (n=302 } \\
\text { dyads) }\end{array}$ & $\begin{array}{l}\text { Quality of } \\
\text { Communication; } \\
\text { family report of } \\
\text { concordance with } \\
\text { clinicians on the } \\
\text { primary goal of } \\
\text { care and treatment } \\
\text { consistent with } \\
\text { preferences. }\end{array}$ & $\begin{array}{l}\text { Those using the goals of Care } \\
\text { decision aid showed better } \\
\text { quality of communication for } \\
\text { nursing staff compared to the } \\
\text { control group ( } 6.0 \text { vs } 5.6 \\
\text { p=0.05) at } 3 \text { months. } \\
\text { Improvement in } \\
\text { communication led to higher } \\
\text { ratings of end of life } \\
\text { communication in the } \\
\text { intervention compared to } \\
\text { control group ( } 3.7 \text { vs } 3.0 \\
\text { p=0.02). Decision makers in } \\
\text { the intervention group } \\
\text { perceived greater concordance } \\
\text { with providers compared to } \\
\text { the control group ( } 88.4 \% \text { vs } \\
71.2 \% \text { p=.0001) at } 9 \text { months } \\
\text { or death. Both arms } \\
\text { increasingly chose comfort } \\
\text { care. } \\
\text { Ratings of treatment } \\
\text { consistent with preferences, } \\
\text { symptom management and } \\
\text { quality of care did not differ. }\end{array}$ & $\begin{array}{l}\text { The GOC decision } \\
\text { was effective in } \\
\text { improving the } \\
\text { quality of } \\
\text { communication } \\
\text { between staff and } \\
\text { caregivers, and } \\
\text { helped to improve } \\
\text { features of palliative } \\
\text { care. }\end{array}$ \\
\hline
\end{tabular}




\begin{tabular}{|c|c|c|c|c|c|c|c|}
\hline & & & & & & $\begin{array}{l}\text { There was more palliative care } \\
\text { content in the treatment plans } \\
\text { in the intervention group by } 6 \\
\text { moths than the control group } \\
\text { ( } 5.6 \text { vs } 4.7, \mathrm{P}=.02 \text { and half as } \\
\text { many hospital transfers ( } 0.078 \\
\text { vs } 0.163 \text { per } 90 \text { person days; } \\
\text { RR, } 0.47 \text {; } 95 \% \text { CI, } 0.26- \\
0.888 \text { ). } \\
\text { Ratings of satisfaction with } \\
\text { care and symptoms } \\
\text { management did not differ } \\
\text { between groups. }\end{array}$ & \\
\hline $\begin{array}{l}\text { Einterz et } \\
\text { al. } \\
\text { (Einterz et } \\
\text { al., 2014) }\end{array}$ & 2014 & $\begin{array}{l}\text { Pre-post } \\
\text { test }\end{array}$ & $\begin{array}{l}\text { See Hanson et al (2017) } \\
\text { (Hanson et al., 2017) }\end{array}$ & $\begin{array}{l}\text { Nursing } \\
\text { home } \\
\text { residents over } \\
65 \text { years with } \\
\text { moderate to } \\
\text { severe } \\
\text { dementia } \\
(\mathrm{n}=18)\end{array}$ & $\begin{array}{l}\text { Surrogate } \\
\text { knowledge, quality } \\
\text { of communication, } \\
\text { surrogate-provider } \\
\text { concordance, and } \\
\text { number of } \\
\text { palliative care } \\
\text { domains addressed } \\
\text { in care plan. }\end{array}$ & $\begin{array}{l}\text { Most participants }(89 \%) \text { felt } \\
\text { the decision aid was relevant } \\
\text { to their needs and not difficult } \\
\text { to use. } \\
\text { Eleven (61\%) thought the care } \\
\text { planning meeting was helpful, } \\
\text { however } 3(17 \%) \text { felt it } \\
\text { covered information they } \\
\text { already knew. }\end{array}$ & $\begin{array}{l}\text { The intervention was } \\
\text { feasible and relevant } \\
\text { for surrogate } \\
\text { decision makers. } \\
\text { Findings suggest it } \\
\text { may improve } \\
\text { communication } \\
\text { between surrogate } \\
\text { decision makers and } \\
\text { nursing home } \\
\text { providers. }\end{array}$ \\
\hline
\end{tabular}




\begin{tabular}{|c|c|c|c|c|c|c|c|}
\hline & & & & & & $\begin{array}{l}\text { Knowledge increased after } \\
\text { viewing the video ( } 12.5 \mathrm{vs} \\
14.2 ; \mathrm{P}<.001) \text {. Quality of } \\
\text { communication scores } \\
\text { increased at } 3 \text { months ( } 6.1 \mathrm{vs} \\
6.8 ; \mathrm{P}=.011 \text { ) and there was } \\
\text { improved concordance of the } \\
\text { primary goal of care with the } \\
\text { nursing home team ( } 50 \% \text { vs } \\
78 \% ; \mathrm{P}=.003 \text { ). The mean } \\
\text { number of palliative care } \\
\text { domains in the care plan also } \\
\text { increased (1.8 vs } 4.3 ; \mathrm{P}<.001 \text { ). }\end{array}$ & \\
\hline $\begin{array}{l}\text { Volandes } \\
\text { et al. } \\
\text { (Volandes } \\
\text { et al., } \\
\text { 2009b) }\end{array}$ & 2009 & RCT & $\begin{array}{l}\text { A video decision aid in } \\
\text { addition to audio } \\
\text { description of advanced } \\
\text { dementia. Intervention } \\
\text { group reviewed the video } \\
\text { decision aid on a } \\
\text { computer. The video } \\
\text { depicts the } \\
\text { characteristics of } \\
\text { advanced dementia, } \\
\text { presented with the case } \\
\text { of an } 80 \text { year old female } \\
\text { patient together with her }\end{array}$ & $\begin{array}{l}\text { Older people } \\
\text { living in the } \\
\text { community } \\
(\mathrm{n}=200)\end{array}$ & $\begin{array}{l}\text { Preferences of } \\
\text { Goals of Care }\end{array}$ & $\begin{array}{l}\text { Verbal narrative alone group: } \\
68 \text { out of } 106(64 \%) \text { chose } \\
\text { comfort care, } 20 \text { out of } 106 \\
\text { (19\%) chose limited care, } 15 \\
\text { out of } 106(14 \%) \text {, chose life } \\
\text { prolonging care and } 3 \% \text { ( } 3 \text { out } \\
\text { of } 106) \text { were uncertain. } \\
\text { Video group: } 81 \text { out of } 94 \\
\text { ( } 86 \%) \text { chose comfort care, } 8 \\
\text { out of } 94,(9 \%) \text { chose limited } \\
\text { care, } 4 \text { out of } 94 \text { ( } 4 \%) \text { chose } \\
\text { life prolonging care and } 1 \\
(1 \%) \text { was uncertain } \chi^{2}=13.0 \text {, }\end{array}$ & $\begin{array}{l}\text { Older people who } \\
\text { saw a video decision } \\
\text { aid of a person with } \\
\text { advanced dementia } \\
\text { after listening to a } \\
\text { verbal narrative of } \\
\text { the condition are } \\
\text { more likely to } \\
\text { choose comfort care } \\
\text { as their goal of care } \\
\text { compared to those } \\
\text { who have only } \\
\text { listened to a verbal } \\
\text { description. }\end{array}$ \\
\hline
\end{tabular}




\begin{tabular}{|c|c|c|c|c|c|c|c|}
\hline & & & $\begin{array}{l}\text { two daughters in a } \\
\text { nursing home setting. } \\
\text { The control group } \\
\text { received just the audio. }\end{array}$ & & & $\begin{array}{l}\mathrm{df}=3, P=0.003 \text { ). A greater } \\
\text { proportion in the video group } \\
\text { chose comfort care (difference } \\
22 \%, 95 \% \text { CI } 11 \% \text { - } 34 \% \text { ). } \\
\text { Factors associated with greater } \\
\text { likelihood of preferring } \\
\text { comfort care among all } \\
\text { participants included; being a } \\
\text { college graduate, good or } \\
\text { better health status, great } \\
\text { health literacy, white race and } \\
\text { randomisation to video group. } \\
\text { Inclusion of these variables in } \\
\text { a multivariable logistic } \\
\text { regression model, participants } \\
\text { in the intervention group were } \\
\text { more likely to choose comfort } \\
\text { care (adjusted odds ratio } 3.9, \\
95 \% \text { CI } 1.8 \text { - 8.6). }\end{array}$ & \\
\hline $\begin{array}{l}\text { Volandes } \\
\text { et al. } \\
\text { (Volandes } \\
\text { et al., } \\
\text { 2009a) }\end{array}$ & 2009 & RCT & $\begin{array}{l}\text { See Volandes et al., } 2009 \\
\text { (Volandes et al., 2009b) }\end{array}$ & $\begin{array}{l}\text { Pairs of } \\
\text { older } \\
\text { residents and } \\
\text { their }\end{array}$ & $\begin{array}{l}\text { Concordance Rate } \\
\text { of Preferences of } \\
\text { Care }\end{array}$ & $\begin{array}{l}\text { Only } 2 \text { out of } 6 \text { surrogates } \\
\text { correctly chose what their } \\
\text { family member wanted in } \\
\text { advanced dementia ( } 33 \% \\
\text { concordance) in the control }\end{array}$ & $\begin{array}{l}\text { Patients and } \\
\text { surrogates viewing a } \\
\text { video decision aid } \\
\text { are more likely to } \\
\text { agree about the }\end{array}$ \\
\hline
\end{tabular}




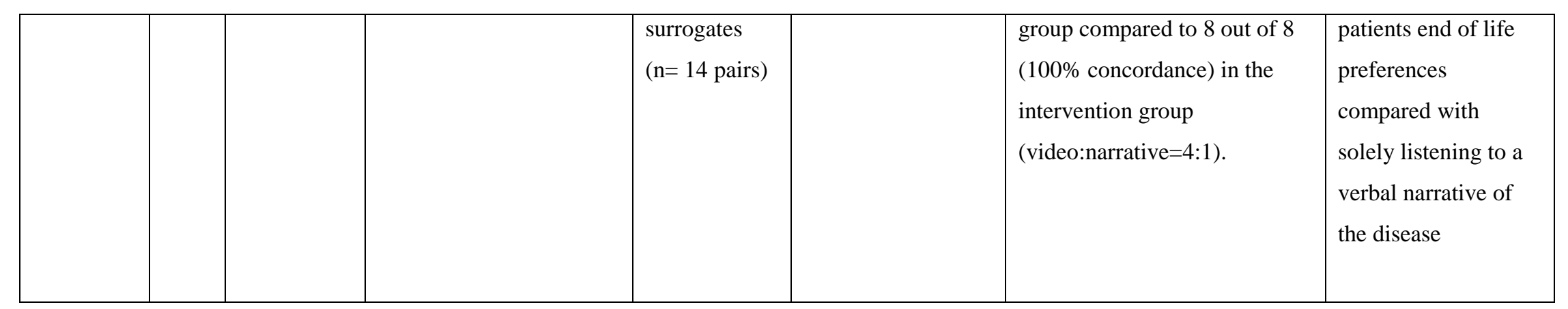

